\title{
Plant growth-promoting traits of biocontrol potential bacteria isolated from rice rhizosphere
}

\author{
Subramaniam Gopalakrishnan ${ }^{1 *}$, HD Upadhyaya ${ }^{1}$, Srinivas Vadlamudi ${ }^{1}$, Pagidi Humayun ${ }^{1}$, Meesala Sree Vidya ${ }^{1}$, \\ Gottumukkala Alekhya ${ }^{1}$, Amit Singh ${ }^{2}$, Rajendran Vijayabharathi ${ }^{1}$, Ratna Kumari Bhimineni ${ }^{1}$, Murali Seema ${ }^{1}$, \\ Abhishek Rathore ${ }^{1}$ and Om Rupela'
}

\begin{abstract}
Seven isolates of bacteria (SRI-156, SRI-158, SRI-178, SRI-211, SRI-229, SRI-305 and SRI-360) were earlier reported by us as having potential for biocontrol of charcoal rot of sorghum and plant growth promotion (PGP) of the plant. In the present study, the seven isolates were characterized for their physiological traits (tolerance to salinity, $\mathrm{pH}$, temperature and resistance to antibiotics and fungicides) and further evaluated in the field for their PGP of rice. All the seven isolates were able to grow at $\mathrm{pH}$ values between 5 and 13, in $\mathrm{NaCl}$ concentrations of up to $8 \%$ (except SRI-156 and SRI-360), temperatures between 20 and $40^{\circ} \mathrm{C}$ and were resistant to ampicillin (>100 ppm; except SRI-158 and SRI-178) but sensitive (<10 ppm) to chloramphenicol, kanamycin, nalidixic acid, streptomycin (except SRI-156 and SRI-211) and tetracycline. They were tolerant to fungicides benlate and captan, except SRI-158 and SRI-178, bavistin and sensitive to thiram (except SRI-156 and SRI-211) at field application level. In the field, four of the seven isolates (SRI-158, SRI-211, SRI-229 and SRI-360) significantly enhanced the tiller numbers, stover and grain yields, total dry matter, root length, volume and dry weight over the un-inoculated control. In the rhizosphere soil at harvest, all the isolates significantly enhanced microbial biomass carbon (except SRI-156), microbial biomass nitrogen and dehydrogenase activity (up to 33\%, 36\% and 39\%, respectively) and total N, available P and\% organic carbon (up to $10 \%, 38 \%$ and $10 \%$, respectively) compared to the control. This investigation further confirms that the SRI isolates have PGP properties.
\end{abstract}

Keywords: Biocontrol, Plant growth promotion (PGP), Rice, Field evaluation, Rhizosphere bacteria

\section{Introduction}

Plant growth - promoting rhizobacteria (PGPR) are the soil bacteria that colonize the roots of plants and enhance plant growth. PGPR can directly or indirectly affect plant growth through various mechanisms. Direct stimulation may include fixation of atmospheric nitrogen (Soares et al. 2006), synthesis of various phytohormones and enzymes (Patten and Glick 2002; Penrose and Glick 2003; Cheng et al. 2007) and solubilization of minerals in plants (Basak and Biswas 2009; Panhwar et al. 2012), while indirect stimulation includes inhibiting phytopathogens (Hao et al. 2011). Actively growing microbes are greater in number in the rhizosphere as crop plants release root exudates that produce, in addition to simple

\footnotetext{
* Correspondence: s.gopalakrishnan@cgiar.org

${ }^{1}$ International Crops Research Institute for the Semi-Arid Tropics (ICRISAT),

Patancheru 502 324, Andhra Pradesh, India

Full list of author information is available at the end of the article
}

and complex sugars and growth regulators, different classes of primary and secondary compounds including amino acids, organic acids, phenolic acids, flavonoids, fatty acids, enzymes, steroids, alkaloids and vitamins (Uren 2000). Researchers around the world attempted to isolate PGPR organisms from the rhizospheres of crop plants.

Seven isolates of bacteria (SRI-156, SRI-158, SRI-178, SRI-211, SRI-229, SRI-305 and SRI-360), isolated from the rhizospheres of a system of rice intensification (SRI) fields, were earlier reported by us as having potential for biocontrol of charcoal rot of sorghum, caused by Macrophomina phaseolina (Tassi) Goid. and plant growth promotion (PGP) of the plant (Gopalakrishnan et al. 2011a). Also, the selected bacterial strains produced siderophore, indole acetic acid (except SRI-305), hydrocyanic acid (except SRI-158 and SRI-305) and solubilized (except SRI-360) phosphorous (Gopalakrishnan et al. 2011a). In

\section{空}


the SRI method of rice cultivation, certain changes are done in the agronomic practices which include the use of much younger seedlings than are normally transplanted, planting them singly and carefully in a square pattern with wide spacing in soil that is kept moist but not continuously flooded and with increased amendments of organic matter and active aeration of the soil during weed control operation preferably with mechanical weeder (Uphoff 2003). The aim of the present study was to characterize and evaluate the PGP potential of seven SRI strains of bacteria in rice, grown under field conditions using the SRI protocols. It was also aimed to evaluate the potential of these PGP strains enhancing tolerance to salinity, $\mathrm{pH}$, high temperature and resistance to antibiotics and fungicides.

\section{Materials and methods}

\section{SRI bacterial isolates}

A total of seven bacteria isolated from rhizosphere of a SRI fields, SRI-156 (Pseudomonas plecoglossicida; NCBI Accession Number: JQ247008), SRI-158 (Brevibacterium antiquum; NCBI Accession Number: JQ247009), SRI178 (Bacillus altitudinis; NCBI Accession Number: JQ247010), SRI-211 (Enterobacter ludwigii; NCBI Accession Number: JQ247011), SRI-229 (E. ludwigii; NCBI Accession Number: JQ247012), SRI-305 (Acinetobacter tandoii; NCBI Accession Number: JQ247013) and SRI360 (P. monteilii; NCBI Accession number: JQ247014), reported earlier by us as potential for biocontrol and PGP traits in sorghum (Gopalakrishnan et al. 2011a), were further studied in this investigation.

\section{Evaluation of SRI isolates for their physiological traits Salinity}

SRI isolates were streaked on Luria Bertani (LB) agar with various concentrations of $\mathrm{NaCl}$ ranging from $0 \%$ to $10 \%$ at the interval of $2 \%$ and incubated at $28^{\circ} \mathrm{C}$ for $72 \mathrm{~h}$.

\section{pH}

The seven SRI isolates were streaked on LB agar, adjusted to $\mathrm{pH} 5,7,9,11$ and 13 and incubated at $28^{\circ} \mathrm{C}$ for three days. For pH 3, LB broth was inoculated with the seven SRI strains and at the end of $72 \mathrm{~h}$ incubation the intensity of growth was measured at $600 \mathrm{~nm}$ in a spectrophotometer.

\section{Temperature}

The seven SRI isolates were streaked on LB agar and incubated at 20,30 and $40^{\circ} \mathrm{C}$ for $72 \mathrm{~h}$. For $50^{\circ} \mathrm{C}$, the $\mathrm{LB}$ broth was inoculated with the seven SRI strains, and at the end of $72 \mathrm{~h}$ incubation, the intensity of growth was measured at $600 \mathrm{~nm}$ in a spectrophotometer.

\section{Antibiotic resistance/susceptible pattern}

A total of six antibiotics viz. ampicillin, chloramphenicol, kanamycin, nalidixic acid, streptomycin and tetracycline were studied for their resistance/susceptible pattern against the seven SRI isolates. The required quantities of antibiotics were dissolved in sterilized Milli Q water and mixed into Nutrient agar just before pouring into the Petri plates (when the temperature of the media was about $50^{\circ} \mathrm{C}$ ). Upon solidification, the SRI isolates were streaked and incubated at $28^{\circ} \mathrm{C}$ for $72 \mathrm{~h}$.

\section{Fungicide tolerance}

SRI isolates were evaluated for their tolerance to fungicides at field application level. A total of four fungicides viz. benlate (benomyl 50\%; methyl [1-[(butylamino) carbonyl]-1H-benzimidazol-2-yl] carbamate), captan (captan 50\%; $N$-trichloromethylthio-4-cyclohexene-1, 2-dicarboximide), bavistin (carbindozim 50\%; methyl benzimidazol-2-ylcarbamate) and thiram (dimethylcarbamothioylsulfanyl $N, N$-dimethylcarbamodithioate) were evaluated at field application levels at 3000, 2500, 4000, 3000 and $3000 \mathrm{ppm}$ concentrations, respectively. The required quantities of fungicides were dissolved in sterilized Milli Q water and mixed into LB agar just before pouring into the Petri plates. Upon solidification, the SRI isolates were streaked and incubated at $28^{\circ} \mathrm{C}$ for $72 \mathrm{~h}$.

Responses of the seven SRI isolates to salinity, $\mathrm{pH}$, temperature, antibiotics and fungicide tolerance were recorded as follows: - = no growth; $+=$ slight growth; $++=$ moderate growth and $+++=$ good growth .

\section{Evaluation of SRI isolates for PGP traits on rice under field conditions \\ Study site}

The experiment was conducted in Kharif 2011 (wet season) at ICRISAT, Patancheru, Andhra Pradesh, India ( $17^{\circ} 53^{\prime \prime} \mathrm{N}$ latitude, $78^{\circ} 27^{\prime \prime} \mathrm{E}$ longitude and $545 \mathrm{~m}$ altitude) with a medium duration rice variety, Sampada (135 days): Soils at the experimental site are classified as sandy loam in texture (55\% sand, $17 \%$ silt and $28 \%$ clay) with alkaline $\mathrm{pH}$ of $8.5-9.0$. The mineral content of the top $15 \mathrm{~cm}$ layer were as follows: available nitrogen $292 \mathrm{~kg} \mathrm{ha}^{-1}$, available phosphorus $26 \mathrm{~kg} \mathrm{ha}^{-1}$, available potassium $527 \mathrm{~kg} \mathrm{ha}^{-1}$ and organic carbon $0.76-1.27 \%$.

\section{Design and treatments}

The experiment was laid out in a randomized complete block design (RCBD) with three replicates and $10 \mathrm{~m} \times$ $7.5 \mathrm{~m}$ subplots. Rice was grown by the system of rice intensification (SRI) method proposed by the Central Rice Research Institute (http://crri.nic.in). The seven SRI isolates were grown on a LB broth at $28^{\circ} \mathrm{C}$ for three days and further evaluated for their PGP traits. The control contained no SRI isolates. 


\section{Protocol for field experiment}

Eleven-day-old single seedlings were uprooted from the nursery, their roots dipped in the respective SRI isolates broth (containing $10^{8} \mathrm{CFU} \mathrm{ml}{ }^{-1}$ ) for $45 \mathrm{~min}$ and transplanted on 4th August 2011 at a spacing of $25 \times 25 \mathrm{~cm}$. Rice plants were inoculated with the SRI strains $\left(1000 \mathrm{ml} ; 10^{8} \mathrm{CFU} \mathrm{ml}{ }^{-1}\right)$ once in 15 days until the flowering stage along with the irrigation water. The recommended dose of NPK $\left(120,60\right.$ and $40 \mathrm{~kg} \mathrm{ha}^{-1}$, respectively) was supplied through compost and organic manures mixed with farm yard manure and rice straw. Water management was done as recommended for the SRI method, i.e. the alternate wetting and drying method of irrigation. After panicle initiation, all the plots were kept flooded with a thin layer of water $(1-2 \mathrm{~cm})$, and all were drained at 15 days before harvest. The crop was harvested manually on 23rd November 2011 and observed for plant height, tiller number, primary and secondary panicle number, panicle length, test seed weight, stover and grain yields and total dry matter. Root samples were collected from 0 to $30 \mathrm{~cm}$ soil profile and analyzed for root length density (EPSON expression1640x, Japan), volume and dry weight (dried in an oven at $70^{\circ} \mathrm{C}$ for $48 \mathrm{~h}$ ). Soil samples were collected from 0 to $15 \mathrm{~cm}$ soil profile at harvest. These were analyzed for soil chemical analysis (\% organic carbon, available phosphorous and total nitrogen as per the protocols of Nelson and Sommers 1982; Olsen and Sommers 1982 and Novozamsky et al. 1983, respectively) and biological analysis (dehydrogenase activity, microbial biomass nitrogen and microbial biomass carbon as per Casida 1977, Brooks et al. 1985 and Anderson and Domsch 1989, respectively).

\section{Data analysis}

For each trait, data were analyzed by using Analysis of Variance (ANOVA) technique, by SAS GLM (General Linear Model) procedure (SAS Inst. 2002-08, SAS V9.3) considering replication and isolates as fixed in RCBD. Depth wise ANOVA was performed for the traits root length, root volume and root dry weight. Isolate means were tested for significance and compared using fishers protected least significant difference (lsd).

\section{Results}

All the SRI isolates grew up to $4 \%$ and none grew at $10 \%$ of $\mathrm{NaCl}$ conditions. But the concentrations of $6 \%$ and $8 \%$ were critical as the isolates showed discriminatory performances in three $\mathrm{NaCl}$ concentrations. At $6 \% \mathrm{NaCl}$, the isolates SRI-156, SRI-211, SRI-229 and SRI-305 exhibited good growth and at $8 \% \mathrm{NaCl}$, the SRI isolates SRI-156 and SRI-360 did not show any growth whereas the others showed poor growth (Table 1). SRI isolates grown under varying $\mathrm{pH}$ showed that none grew till $\mathrm{pH}$
3 and all of them exhibited good growth from $\mathrm{pH} 7$ to $\mathrm{pH}$ 13. A pH of 5 was discriminatory for the isolates and the isolates SRI-156, SRI-229, SRI-305 and SRI-360 showed good growth (Table 1). Temperatures of 20 and $30^{\circ} \mathrm{C}$ were found optimum for the growth of all the isolates while at $40^{\circ} \mathrm{C}$ all but one (SRI-158) exhibited good growth. At $50^{\circ} \mathrm{C}$, a single isolate (SRI-178) showed a moderate growth while others did not grow (Table 1). In the antibiotics resistance/susceptible pattern studies, all the isolates were found resistant to ampicillin (>100 ppm; except SRI-158 and SRI-178) but sensitive $(<10 \mathrm{ppm})$ to chloramphenicol, kanamycin, nalidixic acid, streptomycin (except SRI-156 and SRI-211) and tetracycline (Table 1). When the SRI isolates were evaluated for their fungicide tolerance at field application level, they were tolerant to fungicides benlate and captan (except SRI-158 and SRI-178), bavistin but sensitive to thiram (except SRI-156 and SRI-211; Table 1).

When the SRI isolates were evaluated in the field conditions for their PGP potential against an untreated control, the plots treated with SRI-158, SRI-211, SRI-229 and SRI-360 gave significantly greater grain yield, total dry matter and stover yield (Table 2). Also, these isolates significantly improved the tiller numbers (Table 2), however, no significant improvements were seen on plant height, numbers of primary and secondary panicles, panicle length and test seed weight (data not shown). The plots treated with SRI isolates significantly enhanced the root development at $0-15 \mathrm{~cm}$ depth including root length (except SRI-158 and SRI-305), root volume (except SRI-178) and root dry weight. At $15-30 \mathrm{~cm}$ depth, all the isolates significantly enhanced the root length and root volume but not root dry weight, though all the treatments enhanced the root dry weight, compared to the control (Table 3). Among the SRI isolates, SRI-229 caused greater increases of the yield parameters (including grain yield, stover yield and total dry matter) and root development (including root length, volume and dry weight).

The biological activities, microbial biomass carbon (except SRI-156), microbial biomass nitrogen and dehydrogenase activity, in the top $15 \mathrm{~cm}$ rhizosphere soils at harvest were also found to be significantly higher in the SRI isolates-inoculated treatments over the uninoculated controls (up to 33\%, 36\% and 39\%, respectively; Table 4). The total N, available $\mathrm{P}$, and organic carbon\% were significantly higher in the top $15 \mathrm{~cm}$ of rhizosphere soils of SRI isolates treated plants (up to $10 \%, 38 \%$ and $10 \%$, respectively) at harvesting than those of the un-inoculated control (Table 5).

\section{Discussion}

The SRI isolates used in the present investigation were earlier reported by us as having potential for biocontrol 
Table 1 Effect of salinity, pH, temperature, antibiotics resistance pattern and fungicide tolerance on the growth of SRI isolates

\begin{tabular}{|c|c|c|c|c|c|c|c|}
\hline Traits & SRI-156 & SRI-158 & SRI-178 & SRI-211 & SRI-229 & SRI-305 & SRI-360 \\
\hline \multicolumn{8}{|l|}{ Salinity } \\
\hline 4 & +++ & +++ & +++ & +++ & +++ & +++ & +++ \\
\hline 6 & +++ & ++ & ++ & +++ & +++ & +++ & ++ \\
\hline 8 & - & + & + & + & + & + & - \\
\hline 10 & - & - & - & - & - & - & - \\
\hline \multicolumn{8}{|l|}{$\mathrm{pH}$} \\
\hline 3 & - & - & - & - & - & - & - \\
\hline 5 & +++ & + & ++ & ++ & +++ & +++ & +++ \\
\hline 7 & +++ & ++ & +++ & +++ & +++ & +++ & +++ \\
\hline 9 & +++ & +++ & +++ & +++ & +++ & +++ & +++ \\
\hline 11 & +++ & +++ & +++ & +++ & +++ & +++ & +++ \\
\hline 13 & +++ & +++ & +++ & +++ & +++ & +++ & +++ \\
\hline \multicolumn{8}{|l|}{ Temperature $\left({ }^{\circ} \mathrm{C}\right)$} \\
\hline 20 & +++ & +++ & +++ & +++ & +++ & +++ & +++ \\
\hline 30 & +++ & ++ & +++ & +++ & +++ & +++ & +++ \\
\hline 40 & +++ & + & +++ & +++ & +++ & +++ & +++ \\
\hline 50 & - & - & ++ & - & - & - & - \\
\hline \multicolumn{8}{|c|}{ Antibiotics resistance pattern (ppm) } \\
\hline Ampicillin & 100 & 10 & 1 & 100 & 100 & 100 & 100 \\
\hline Chloramphenicol & 5 & 2.5 & 10 & 10 & 10 & 10 & 10 \\
\hline Kanamycin & 1 & 1 & 0 & 1 & 10 & 0 & 10 \\
\hline Nalidixic acid & 10 & 1 & 0 & 10 & 10 & 0 & 10 \\
\hline Streptomycin & 40 & 0 & 0 & 20 & 10 & 0 & 5 \\
\hline Tetracyline & 10 & 1 & 10 & 10 & 5 & 10 & 5 \\
\hline \multicolumn{8}{|l|}{ Fungicide tolerance } \\
\hline Thiram @ 3000 ppm & ++ & - & - & ++ & - & - & - \\
\hline Bavistin@2500 ppm & +++ & + & +++ & +++ & +++ & +++ & +++ \\
\hline Benlate @ 4000 ppm & +++ & - & - & +++ & +++ & +++ & +++ \\
\hline Captan@ 3000 ppm & +++ & - & - & +++ & ++ & + & ++ \\
\hline
\end{tabular}

$+++=$ good growth; ++ = medium growth; + = poor growth; - = no growth

of charcoal rot of sorghum, caused by M. phaseolina and PGP of the plant (Gopalakrishnan et al. 2011a). In the present study, all the seven SRI isolates were able to grow at $\mathrm{pH}$ levels between 5 and 13, in $\mathrm{NaCl}$ up to $6 \%$ and temperatures between 20 and $40^{\circ} \mathrm{C}$. SRI-178, identified as Bacillus altitudinis in our previous study (Gopalakrishnan et al. 2011a), was found to grow moderately even at $50^{\circ} \mathrm{C}$, probably because of its spore-forming nature. Hence, it can be concluded that these isolates may have the ability to survive in the harsh environments such as saline and acidic to alkaline $\mathrm{pH}$ soils. Also, they were highly sensitive $(<10 \mathrm{ppm})$ to chloramphenicol, kanamycin, nalidixic acid, streptomycin (except SRI-156 and SRI-211) and tetracycline and resistant to ampicillin (>100 ppm; except SRI-158 and SRI-178); these antibiotics could be used as markers for their identification in field evaluation studies. Further, all the SRI isolates were tolerant to bavistin, except SRI-158 and SRI178 which were found tolerant to benlate and captan at field application level indicating their compatibility with fungicides, and hence can be a useful component of integrated pest and disease management program.

Four out of the seven isolates used in this investigation (SRI-158, SRI-211, SRI-229 and SRI-360) were found to significantly enhance growth parameters (including stover and grain yields, total dry matter, root length, volume and dry weight) and biological and chemical parameters (including microbial biomass carbon, microbial biomass nitrogen, dehydrogenase activity, total $\mathrm{N}$, available $\mathrm{P}$ and\% organic carbon). The mechanism by 
Table 2 Effect of SRI isolates on the morphology and yield potential of rice cultivation

\begin{tabular}{|c|c|c|c|c|}
\hline Treatment & $\begin{array}{l}\text { No. of } \\
\text { tillers } \\
\left(\mathrm{m}^{-2}\right)\end{array}$ & $\begin{array}{l}\text { Stover } \\
\text { yield } \\
\left(\mathrm{g} \mathrm{m}^{-2}\right)\end{array}$ & $\begin{array}{l}\text { Grain } \\
\text { yield } \\
\left(\mathrm{g} \mathrm{m}^{-2}\right)\end{array}$ & $\begin{array}{l}\text { Total dry } \\
\text { matter } \\
\left(\mathrm{g} \mathrm{m}^{-2}\right)\end{array}$ \\
\hline SRI-156 & 360 & 558 & 540 & 1098 \\
\hline SRI-158 & 523 & 685 & 643 & 1328 \\
\hline SRI-178 & 571 & 635 & 583 & 1218 \\
\hline SRI-211 & 470 & 663 & 595 & 1258 \\
\hline SRI-229 & 538 & 684 & 673 & 1357 \\
\hline SRI-305 & 662 & 605 & 628 & 1233 \\
\hline SRI-360 & 453 & 683 & 650 & 1333 \\
\hline Control & 451 & 604 & 582 & 1186 \\
\hline Mean & 504 & 640 & 612 & 1251 \\
\hline $\mathrm{SE} \pm$ & $31.6^{* * *}$ & $19.7^{* *}$ & $17.5^{* *}$ & $30.0^{* * *}$ \\
\hline LSD (5\%) & 91.8 & 59.8 & 53.1 & 90.9 \\
\hline CV\% & 14 & 5 & 5 & 4 \\
\hline
\end{tabular}

$\mathrm{SE}=$ standard error; $\mathrm{LSD}=$ least significant difference; $\mathrm{CV}=$ coefficient of variance; ${ }^{*}=$ statistically significant at $0.05 ;{ }^{* *}=$ statistically significant at 0.01 ; $*^{* * *}=$ statistically significant at 0.001 .

which the SRI isolates enhanced the morphological observations could be their PGP attributes such as indole acetic acid (IAA), siderophore production and phosphate solubilization (Gopalakrishnan et al. 2011a). IAA - producing microorganisms are known to promote root elongation and plant growth (Patten and Glick 2002), while siderophore producers act by binding $\mathrm{Fe}^{3+}$ from the environment and making it available to the plant (Wang et al. 1993). Free-living phosphatesolubilizing microbes release phosphate ions from sparing soluble inorganic and organic P compounds in soils and thereby contribute to an increased soil phosphate
Table 4 Effect of SRI isolates on soil biological activity at harvesting stage of rice cultivation

\begin{tabular}{llll}
\hline Treatment & $\begin{array}{l}\text { Microbial } \\
\text { biomass carbon } \\
\left(\boldsymbol{\mu} \mathbf{g ~ g}^{-1} \text { soil) }\right.\end{array}$ & $\begin{array}{l}\text { Microbial } \\
\text { biomass nitrogen } \\
\left(\boldsymbol{\mu} \mathbf{g ~ g}^{-1} \text { soil) }\right.\end{array}$ & $\begin{array}{l}\text { Dehydrogenase } \\
\text { activity }\left(\boldsymbol{\mu g} \text { TPF }^{-1}\right. \\
\left.\text { soil } \mathbf{2 4} \mathbf{~ h}^{-1}\right)\end{array}$ \\
\hline SRI-156 & 2625 & 62 & 115 \\
SRI-158 & 2876 & 71 & 120 \\
SRI-178 & 3448 & 67 & 152 \\
SRI-211 & 3129 & 80 & 133 \\
SRI-229 & 3050 & 68 & 142 \\
SRI-305 & 3776 & 75 & 131 \\
SRI-360 & 3774 & 74 & 154 \\
Control & 2845 & 58 & 111 \\
Mean & 3190 & 69 & 132 \\
SE \pm & $177.3^{* *}$ & $2.2^{* * *}$ & $8.6^{*}$ \\
LSD (5\%) & 567.2 & 7.0 & 26.1 \\
CV\% & 10 & 5 & 11 \\
\hline
\end{tabular}

SE = standard error; $L S D=$ least significance difference; $C V=$ coefficient of variance; * = statistically significant at $0.05 ;{ }^{* *}=$ statistically significant at 0.01 ; $* * *=$ statistically significant at 0.001 .

pool available for the plants (Artursson et al. 2006) The interaction between soil microorganisms and roots and their possible impacts on plant growth have been studied by Birkhofer et al. (2008) and Uphoff et al. (2009). When the soils were made wet and then dry, as in the case of the SRI method of rice cultivation, the levels of available $\mathrm{P}$ in the soil solution increased between $185 \%$ and $1900 \%$ as a result of population dynamics of species of phosphate-solubilizing bacteria and fungi (Turner and Haygarth 2001). Gayathry (2002) found that the counts of bacteria, such as the diazotrophs, Azospirillum, Azotobacter and phosphobacteria

Table 3 Effect of SRI isolates on the root development of rice at harvesting stage of rice cultivation

\begin{tabular}{|c|c|c|c|c|c|c|}
\hline \multirow[b]{2}{*}{ Treatment } & \multicolumn{2}{|c|}{ Root length $\left(\mathrm{mm}^{-2}\right)$} & \multicolumn{2}{|c|}{ Root volume $\left(\mathrm{cm}^{3} \mathrm{~m}^{-2}\right)$} & \multicolumn{2}{|c|}{ Root dry weight $\left(\mathrm{g} \mathrm{m}^{-2}\right)$} \\
\hline & $0-15 \mathrm{~cm}$ & $15-30 \mathrm{~cm}$ & $0-15 \mathrm{~cm}$ & $15-30 \mathrm{~cm}$ & $0-15 \mathrm{~cm}$ & $15-30 \mathrm{~cm}$ \\
\hline SRI-156 & 5312 & 996 & 901 & 152 & 63.9 & 8.2 \\
\hline SRI-158 & 4979 & 711 & 859 & 106 & 60.2 & 5.9 \\
\hline SRI-178 & 5230 & 817 & 839 & 107 & 59.9 & 6.6 \\
\hline SRI-211 & 6542 & 781 & 1183 & 189 & 82.9 & 8.6 \\
\hline SRI-229 & 6389 & 922 & 1120 & 117 & 89.2 & 6.4 \\
\hline SRI-305 & 5004 & 887 & 903 & 112 & 66.9 & 6.4 \\
\hline SRI-360 & 5036 & 800 & 1065 & 112 & 72.9 & 6.7 \\
\hline Control & 5019 & 509 & 840 & 89 & 47.1 & 5.6 \\
\hline Mean & 5413 & 783 & 953 & 118 & 68.9 & 6.6 \\
\hline SE \pm & $164.9^{* * *}$ & $87.1^{*}$ & $27.7^{* * *}$ & $11.1^{* *}$ & $4.7^{* *}$ & $1.1^{\mathrm{NS}}$ \\
\hline LSD (5\%) & 516.9 & 274.2 & 86.9 & 35.3 & 14.9 & - \\
\hline CV\% & 4.6 & 16.9 & 4.4 & 13.9 & 10.4 & 25.1 \\
\hline
\end{tabular}

$\mathrm{SE}=$ standard error; $\mathrm{LSD}=$ least significant difference; $\mathrm{CV}=$ coefficient of variation; $\mathrm{NS}=$ not significant; ${ }^{*}=$ statistically significant at $0.05 ;{ }^{* *}=$ statistically significant at $0.01{ }^{* * *}=$ statistically significant at 0.001 . 
Table 5 Effect of SRI isolates on soil chemical activity at harvesting stage of rice cultivation

\begin{tabular}{llll}
\hline Treatment & $\begin{array}{l}\text { Total nitrogen } \\
(\mathbf{p p m})\end{array}$ & $\begin{array}{l}\text { Available phosphorous } \\
(\mathbf{p p m})\end{array}$ & $\begin{array}{l}\text { Organic } \\
\text { carbon }\end{array}$ \\
\hline SRI-156 & 2015 & 116 & 1.52 \\
SRI-158 & 1967 & 121 & 1.48 \\
SRI-178 & 2134 & 117 & 1.57 \\
SRI-211 & 1930 & 106 & 1.61 \\
SRI-229 & 2027 & 102 & 1.61 \\
SRI-305 & 2072 & 91 & 1.51 \\
SRI-360 & 1961 & 88 & 1.56 \\
Control & 1926 & 87 & 1.47 \\
Mean & 2004 & 103 & 1.54 \\
SE \pm & $21.3^{* * *}$ & $5.8^{*}$ & $0.027^{*}$ \\
LSD (5\%) & 71.2 & 19.3 & 0.090 \\
CV\% & 2 & 8 & 4 \\
\hline SEE & & 87.3
\end{tabular}

$\mathrm{SE}=$ standard error; $\mathrm{LSD}=$ least significance difference; $\mathrm{CV}=$ coefficient of variance; $^{*}=$ statistically significant at $0.05 ;{ }^{* * *}=$ statistically significant at 0.001 .

and microbial enzyme activity such as dehydrogenase, urease acid phosphatase, alkaline phosphatase and nitrogenase were significantly higher in SRI rhizospheres than those of the same variety of rice plants grown conventionally. In the present investigation, such enhanced activities were found only in the SRI isolates-inoculated treatments.

Colonization of roots by SRI isolates at the right place and time is essential for enhanced PGP activity. Successful interactions depend on sufficient population density, rhizosphere competence, root colonizing ability and PGP ability of the bacteria (Lugtenberg and Dekkers 1999). Although roots were not inspected for colonization in this study, the data on morphological (including roots), biological and chemical studies strongly suggest that SRI isolates had multiplied and colonized the inoculated rice roots. Hence, it can be concluded that the seven SRI isolates used in this study were apparently well adapted to the rice rhizosphere environment and enhanced the plant growth.

The seven isolates of SRI used in this study were apparently well adopted not only in the sorghum rhizosphere environment (Gopalakrishnan et al. 2011a) but also in the rice rhizosphere where they promoted plant growth. Hence, these isolates could be used as PGP agents in addition to biocontrol agents for the control of charcoal rot. The broad range of PGP and antifungal activities of the seven SRI isolates demonstrates multiple mechanisms of actions including antibiosis, production of cell wall degrading enzymes and plant growth promoting hormones indicating its broad spectrum activity. Broad spectrum PGP and biocontrol agents (and their secondary metabolites) offer potentially effective novel strategies for controlling multiple pathogens and insect pests. A few of the available broad spectrum agents, mostly belonging to Pseudomonas spp., have shown broad spectrum antifungal activity by virtue of volatile and diffusible antibiotics (Hass and Keel 2003; Viji et al. 2003). Bacterial strains from diverse habitats of groundnut with broad spectrum PGP and antifungal activity have been isolated, identified and tested as a seed treatment for the control of collar rot in groundnut with or without thiram (Kishore et al. 2005). Secondary metabolites of $P$. aeruginosa possess antifungal, PGP and biocontrol activities (Bano and Musarrat 2003). ICRISAT has identified actinomycetes (isolated from various herbal composts) and bacteria that inhibit Fusarium oxysporum f. sp. ciceri, Rhizoctonia bataticola, M. phaseolina, Helicoverpa armigera and Spodoptera litura (Gopalakrishnan et al. 2011b,c,d). The seven broad spectrum potential SRI isolates therefore are likely to be the potential candidates for the discovery of novel secondary metabolites which may be of importance for both PGP and biocontrol applications.

\section{Competing interests}

All the authors declare that they have no competing interests.

\section{Authors' contributions}

SG, HDU, SV, PH, MSV, GA, AS, RV, RKB and MS carried out the physiological traits and field studies, AR done the statistical analysis and SG, SV and OP drafted the manuscript. All authors read and approved the final manuscript.

\section{Acknowledgements}

We thank the Department of Biotechnology, Ministry of Science and Technology, Government of India and the National Bureau of Agriculturally Important Microorganisms for providing financial support. We also thank all the staff of the Biocontrol Unit of ICRISAT including M/s PVS Prasad, P Manohar, B Nagappa, D Barath, A Jabbar and S Rohini for their significant inputs in the laboratory and field studies.

\section{Author details}

${ }^{1}$ International Crops Research Institute for the Semi-Arid Tropics (ICRISAT), Patancheru 502 324, Andhra Pradesh, India. 'Department of Plant Breeding, CCS Haryana Agricultural University, Hisar 125 004, Haryana, India.

Received: 12 October 2012 Accepted: 13 December 2012

Published: 18 December 2012

\section{References}

Anderson TH, Domsch KH (1989) Ratios of microbial biomass carbon to total organic carbon in arable soils. Soil Biol Biochem 21:471-479

Artursson V, Finlay RD, Jansson JK (2006) Interactions between arbascular mycorrhizal fungi and bacteria and their potential for stimulating plant growth. Environ Microbiol 8(1):1-10

Bano N, Musarrat J (2003) Characterization of a new Pseudomonas aeruginosa strain Nj-15 as a potential biocontrol agent. Cur Microbiol 46:324-328

Basak BB, Biswas DR (2009) Influence of potassium solubilizing microorganisms (Bacillus mucilaginosus) and waste mica on potassium uptake dynamics by sudan grass (Sorghum vulgare Pers.) grown under two Alfisols. Plant Soil 317:235-255

Birkhofer K, Bezemer TM, Bloem J, Bonokowski M, Chritensen S, Dubois D, Ekelund F, Fliessbach A, Gunst L, Hedlund K, Mader P, Mikola J, Robin C, Setala H, Tatin-Froux F, Van der Putten W, Scheu S (2008) Long-term organic farming fosters below and above ground biota; implications for soil quality, biological control and productivity. Soil Biol Biochem 40:2297-2308 
Brooks PC, Landman A, Pruden G, Jenkinson DS (1985) Chloroform fumigation and the release of soil nitrogen; a rapid direct extraction method to measure microbial biomass nitrogen in soil. Soil Biol Biochem 17:837-842

Casida LE (1977) Microbial metabolic activity in soil as measured by dehydrogenase determinations. Appl Environ Microbiol 34:630-636

Cheng Z, Park E, Glick BR (2007) 1-Aminocyclopropane-1-carboxylate deaminase from Pseudomonas putida UW4 facilitates the growth of canola in the presence of salt. Can J Microbiol 53:912-918

Gayathry G (2002) Studies on dynamics of soil microbes in rice rhizosphere with water saving irrigation and in-situ weed incorporation. Ph.D. Thesis submitted to Tamil Nadu Agricultural University, Coimbatore, India

Gopalakrishnan S, Humayun P, Kiran BK, Kannan IGK, Vidya MS, Deepthi K, Rupela O (2011a) Evaluation of bacteria isolated from rice rhizosphere for biological control of sorghum caused by M. phaseolina. World J Microbiol Biotechnol 27:1313-1321

Gopalakrishnan S, Kiran BK, Humayun P, Vidya MS, Deepthi K, Rupela O (2011b) Biocontrol of charcoal-rot of sorghum by actinomycetes isolated from herbal vermi-compost. Afr J Biotechnol 10:18142-18152

Gopalakrishnan S, Pande S, Sharma M, Humayun P, Kiran BK, Sandeep D, Vidya MS, Deepthi K, Rupela O (2011c) Evaluation of actinomycete isolates obtained from herbal vermi-compost for biological control of Fusarium wilt of chickpea. Crop Prot 30:1070-1078

Gopalakrishnan S, Ranga Rao GV, Humayun P, Rao VR, Alekhya G, Jacob S, Deepthi K, Vidya MS, Srinivas V, Mamatha L, Rupela O (2011d) Efficacy of botanical extracts and entomopathogens on control of Helicoverpa armigera and Spodoptera litura. Afr J Biotechnol 10:16667-16673

Hao D, Gao P, Liu P, Zhao J, Wang Y, Yang W, Lu Y, Shi T, Zhang X (2011) AC333, a novel secretory protein, inhibits Elk1 transcriptional activity via ERK pathway. Mol Biol Rep 38:1375-1382

Hass D, Keel C (2003) Regulation of antibiotic production in root-colonized Pseudomonas spp. and relevance for biological control of plant disease. Annu Rev Phytopathol 41:117-153

Kishore GK, Pande S, Podile AR (2005) Biological control of collar rot disease with broad spectrum antifungal bacteria associated with groundnut. Can J Microbiol 51:122-132

Lugtenberg BJJ, Dekkers LC (1999) What makes Pseudomonas bacteria rhizosphere competent? Environ Microbiol 1:9-13

Nelson DW, Sommers LE (1982) Total organic carbon and organic matter. In: Page AL, Miller RH, Keeney DR (eds) 'Methods of soil analysis', Part 3, Chemical and microbiological properties. Madison, WI, SSSA, pp 539-579

Novozamsky I, Houba VJG, Van ECKR, vanVark W (1983) A novel digestion technique for multiple element analysis. Commun Soil Sci Plant Anal 14:239-249

Olsen SR, Sommers LE (1982) Phosphorus'. In: Page AL (ed) Methods of soil analysis, Agron No. 9, Part 2, chemical and microbial properties, 2nd edn. Am Soc Agron, Madison, WI, USA, pp 403-430

Panhwar QA, Othman R, Rahman ZA, Meon S, Ismail MR (2012) Isolation and characterization of phosphate-solubilizing bacteria from aerobic rice. Afr J Biotechnol 11:2711-2719

Patten C, Glick CR (2002) Role of Pseudomonas putida indol acetic acid in development of host plant root system. Appl Environ Microbiol 68:3795-3801

Penrose DM, Glick BR (2003) Methods for isolating and characterizing ACC deaminase-containing plant growth-promoting rhizo-bacteria. Physiol Plantarum 118:10-15

Soares RA, Roesch LPW, Zanatta G, Camargo FAD, Passaglia LMP (2006) Occurrence and distribution of nitrogen fixing bacterial community associated with oat (Avena sativa) assessed by molecular and microbiological techniques. Appl Soil Ecol 33:221-234

Turner BL, Haygarth PM (2001) Phosphorous solublization in rewetted soils. Nature 411:258

Uren NC (2000) Types, amounts and possible functions of compounds released into the rhizosphere by soil-grown plants. In: Pinto R, Varanini Z, Nannipieri P (eds) The rhizosphere: biochemistry and organic substances at the soil-plant interface. Marcel Dekker, New York, pp 19-40
Uphoff N (2003) Higher yields with fewer external inputs? The system of rice intensification and potential contributions to agricultural sustainability. Int J Agric Sustain 1:38-50

Uphoff N, Anas I, Rupela OP, Thakur AK, Thyagarajan TM (2009) Learning about positive plant-microbial interactions from the system of rice intensification (SRI). Aspect Appl Biol 98:29-54

Viji G, Uddin W, Romaine CP (2003) Suppression of gray leaf spot (blast) of perennial ryegrass turf by Pseudomonas aeruginosa from spent mushroom substrate. Biol Control 26:379-407

Wang Y, Brown HN, Crowley DE, Szaniszlo P (1993) Evidence for direct utilization of a siderophore, ferrioxamine B, in axenically grown cucumber. Plant Cell Environ 16:579-585

\section{doi:10.1186/2193-1801-1-71}

Cite this article as: Gopalakrishnan et al:: Plant growth-promoting traits of biocontrol potential bacteria isolated from rice rhizosphere. SpringerPlus 2012 1:71.

\section{Submit your manuscript to a SpringerOpen ${ }^{\circ}$ journal and benefit from:}

- Convenient online submission

$\checkmark$ Rigorous peer review

- Immediate publication on acceptance

- Open access: articles freely available online

- High visibility within the field

- Retaining the copyright to your article

Submit your next manuscript at $>$ springeropen.com 